\title{
Airborne laser swath mapping of the Denton Hills, Transantarctic Mountains, Antarctica: Applications for structural and glacial geomorphic mapping
}

\author{
Terry Wilson ${ }^{1}$ and Beata Csathó ${ }^{2}$
}

'School of Earth Sciences, 125 S. Oval Mall, Ohio State University, Columbus, OH 43210-1522, USA wilson.43@osu.edu

${ }^{2}$ Department of Geology, University at Buffalo, 855 Natural Sciences Complex, Buffalo, NY 14260-3050, USA bcsatho@buffalo.edu

\begin{abstract}
High-resolution digital elevation data acquired by airborne laser scanning (ALS) for the Denton Hills, along the coastal foothills of the Royal Society Range, Transantarctic Mountains, are examined for applications to bedrock and glacial geomorphic mapping. Digital elevation models (DEMs), displayed as shaded-relief images and slope maps, portray geomorphic landscape features in unprecedented detail across the region. Structures of both ductile and brittle origin, ranging in age from the Paleozoic to the Quaternary, can be mapped from the DEMs. Glacial features, providing a record of the limits of grounded ice, of lake paleoshorelines, and of proglacial lake-ice conveyor deposits, are also prominent on the DEMs. The ALS-derived topographic data have great potential for a range of mapping applications in regions of ice-free terrain in Antarctica.
\end{abstract}

Citation: Wilson, T.J., and B. Csathó (2007), Airborne laser swath mapping of the Denton Hills, Transantarctic Mountains, Antarctica: Applications for structural and glacial geomorphic mapping: in Antarctica: A Keystone in a Changing World - Online Proceedings of the 10th ISAES, edited by A.K. Cooper and C.R. Raymond et al., USGS Open-File Report 2007-1047, Short Research Paper 089, 6 p.; doi:10.3133/of2007-1047.srp089

\section{Introduction}

Remote sensing is an ideal approach to obtain new geological information for remote and inaccessible regions such as Antarctica. Until recently, however, the resolution of image and topographic data has been insufficient for many geological mapping applications. Airborne Laser Scanning (ALS), also referred to as 'LIght Detection And Ranging' (LIDAR), uses laser ranging from aircraft platforms to map surface topography in unprecedented detail (e.g., Carter et al., 2001). The highresolution topographic data from ALS has been shown to be particularly effective for mapping geomorphic features formed by glacial and active tectonic processes (e.g., Haugerud et al., 2003; Cunningham et al., 2006; Atkins and Dickinson, 2007). In the austral summer of 20012002, NASA's Airborne Topographic Mapper (ATM) system was deployed to Antarctica under the joint auspices of NASA, NSF and the USGS (Csatho et al., 2005). Almost $4,000 \mathrm{~km}^{2}$ of ALS data were collected over several sites in the McMurdo Sound region. One target area, the Denton Hills region located in the coastal foothills of the Royal Society Range of the Transantarctic Mountains (Figure 1), was selected primarily to investigate the capabilities of high-resolution topographic data for mapping of bedrock geology and structure. Geoscience application of ALS data is still in the early stages of development, and there has been little investigation to date of the use of high-resolution data to map landscapes recording ancient structural features. Here we provide examples that illustrate the potential for mapping both ductile and brittle structural features in exposed bedrock and a variety of geomorphicallyexpressed glacial deposits that overlie the bedrock.

\section{Geologic Setting}

The modern Transantarctic Mountains, an intracontinental mountain belt with elevations exceeding $4000 \mathrm{~m}$, are a Mesozoic-Cenozoic rift-flank uplift nucleated on the Paleozoic Ross orogenic belt, which formed due to convergent tectonics along the Neoproterozoic-Early Paleozoic Gondwanaland margin. Bedrock exposures along the eastern flank of the mountains consist of igneous and metasedimentary rock units deformed during the Ross orogeny (Stump, 1995). The coastal margin of the mountains is bounded by a major fault zone known as the Transantarctic Mountains Front, which defines the western limit of the West Antarctic rift system, and the edge of the rift-flank uplift (Figure 1).

The Denton Hills are the coastal foothills of the Royal Society Range, containing largely ice-free valleys between broad ridges with elevations of $\sim 1000 \mathrm{~m}$ (Figure 2). Sugden et al. (1999) proposed that this region was overridden by grounded ice during Miocene expansion of the ice sheet, and that areal scouring during this event

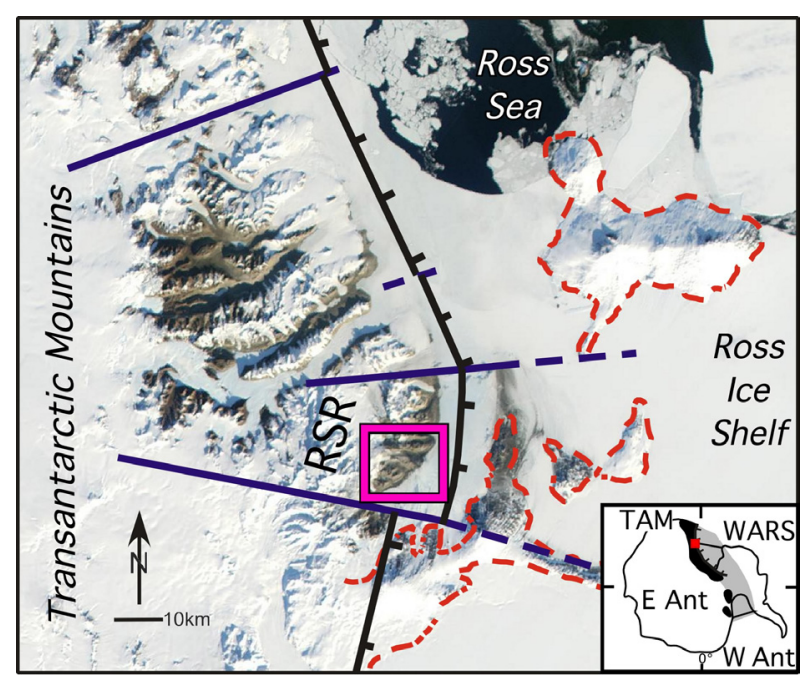

Figure 1. Box outlines the Denton Hills region in the coastal foothills of the Royal Society Range (RSR), Transantarctic Mountains of southern Victoria Land, shown in Figure 2. The Transantarctic Mountains Front fault zone denoted by black line with tick marks. 
removed any surficial regolith, cleanly exposing bedrock structures.

Denton Hills is a region with extensive ice-free terrain, similar to the Dry Valleys area in the Transantarctic Mountains further north, that retains a suite of surficial deposits recording glacial history along the zone where the ice sheets of East and West Antarctica have interacted in the past (e.g., Denton and Marchant, 2000). At the last glacial maximum (LGM) a thick, grounded ice sheet advanced into the mouths of the Denton Hills valleys adjacent to the coast, and the valleys filled with proglacial lakes associated with deposits interpreted to have been deposited by the 'lake-ice conveyor' mechanism (e.g., Clayton-Greene et al., 1998; Hall et al., 2006).

\section{Data Acquisition and Processing}

NASA's Airborne Topographic Mapper (ATM) system measures the range from the aircraft to the ground with a pulsed green laser. The system scans underneath the aircraft at an approximately 15-degree off-nadir angle with a scanner rotation rate of $20 \mathrm{~Hz}$ and a laser pulse rate of $5 \mathrm{kHz}$. The beam is directed toward the surface by a nutating mirror producing a conical scan pattern consisting of a set of overlapping spirals of data points as the aircraft moves forward. At the nominal flight height of 500 meters above the surface and a speed of $50 \mathrm{~m} / \mathrm{sec}$, the laser spot diameter is approximately $1 \mathrm{~m}$. An area of 600 $\mathrm{km}^{2}$ was mapped with the ATM system at the Denton Hills site with an average density of laser spots of at least one laser point per $6 \mathrm{~m}^{2}$. The survey was flown along the valleys and ridges, with swaths oriented in an E-W direction in the north and WNW-ESE in the south.

The first step in data processing, carried out by NASA as described in Krabill et al. (2002), consists of computing the latitude, longitude, and elevation for each laser pulse by combining the laser range with differential GPS aircraft position and inertial navigation attitude. The ATM data set also includes the intensity of reflected laser energy for each footprint as well as the intensity of reflected solar radiation, detected between two consecutive laser rangings. A software package developed at the Photogrammetric Computer Vision Laboratory (PCVL) of The Ohio State University was used for laser point postprocessing (Csatho et al., 2001). First the outlier observations were detected by comparing laser points along the scan pattern, by comparing neighboring scans and by analyzing the elevation distribution in 4 by 4 meter grid cells. Then the refined point cloud was interpolated by computing surface elevations at each grid post from planes fitted through all points within the grid cell. Finally, the interpolated grid was examined by using median filtering and by visual inspection to detect remaining outliers. Grid cells were labeled according to the distribution of the laser points within each cell, and to the RMS error of plane fitting. Grid labels, stored in so called label files, could be used for assessing the reliability of elevations at each individual grid post, and for identifying artifacts that sometimes occur in regions with sparse laser coverage.

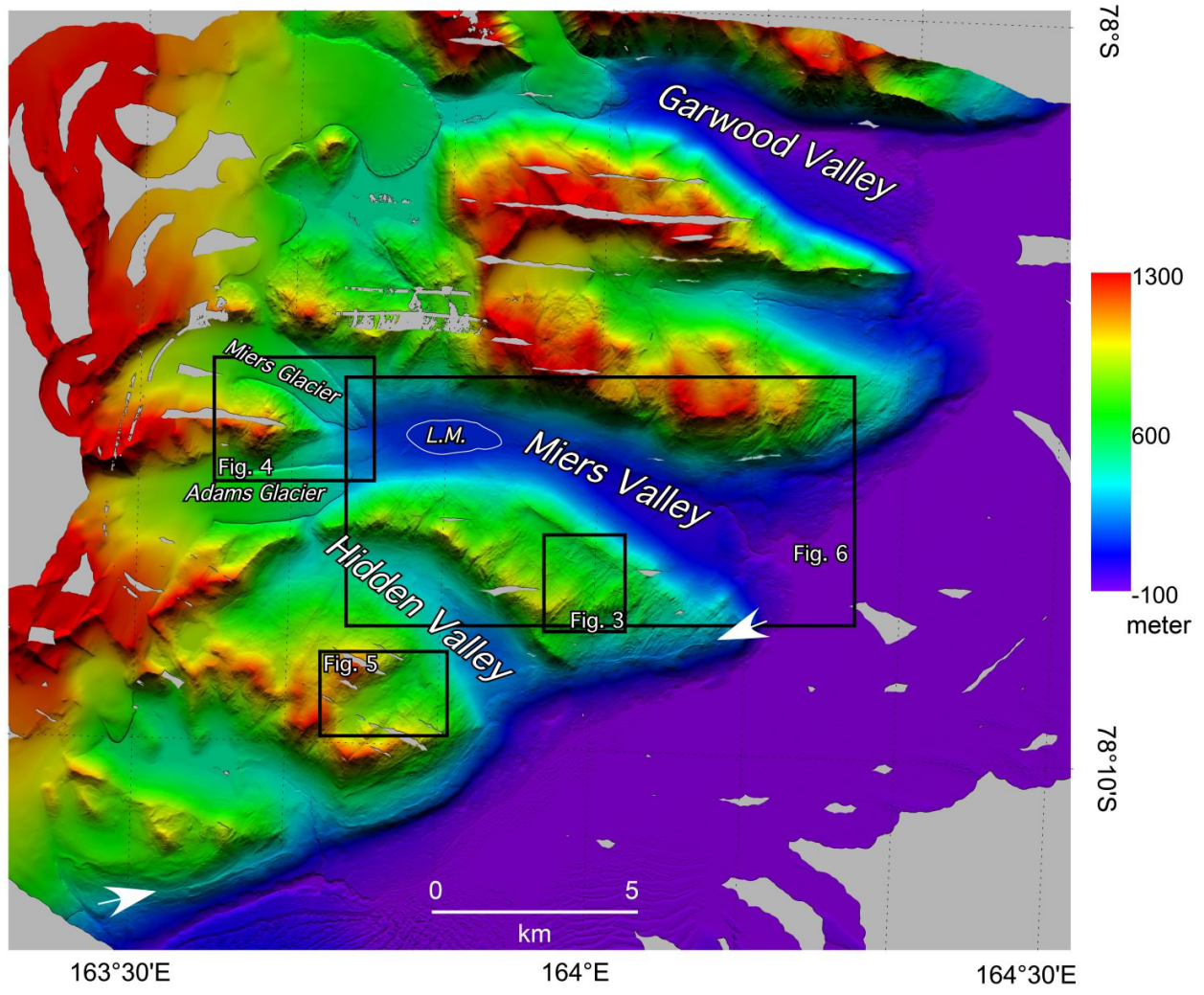

Figure 2. Shaded-relief image of ALS-derived DEM of the Denton Hills. Location shown on Figure 1. Color ramp shows elevation. Grey patches inside the mapped area are data gaps where laser swaths did not overlap. L.M.: Lake Miers. White arrows point to limit of Ross Sea drift, deposited by grounded ice during the Last Glacial Maximum. Locations of subsequent figures shown. 
Precise elevations obtained by differential carrier phase processing of data from geodetic GPS receivers were used to assess the accuracy of the DEMs. Comparison of the complete DEM data set of the McMurdo Sound region (19 DEMs total) with elevations from irregularly distributed GPS stations indicates a vertical accuracy of $0.2 \mathrm{~m}$ (Csatho et al., 2005). Our previous work has shown that the refined laser point clouds and DEMs are free of outliers and systematic errors, giving a faithful representation of the topographic surface (Csatho et al., 2005; Lyons et al., 2005). For this study, the DEMs were manipulated by producing shaded-relief images, a color ramp image showing the range of elevation, and a slope map that classifies slopes between horizontal and $>30^{\circ}$ in grayscale tones, in order to enhance features of geological interest in the study area.

\section{Structural mapping}

The extensive ice- and regolith-free outcrops of the Denton Hills region provides an ideal setting to examine the geomorphic expression of structural features on the high-resolution DEMs derived from the ATM data. Structures ranging in age from Paleozoic to Quaternary can be recognized on the shaded-relief and slope images derived from the DEM. Here we present a selection of key examples that illustrate how bedrock structures can be identified and mapped from ALS-derived topographic data.

\section{Ross Orogen structure}

The structural fabrics formed by ductile deformation during the Ross orogeny are clearly manifested on the ALS DEM. Jones (1997) mapped the structural geology of the Hidden Valley region, and recorded the dominant northwest-southeast orientation of ductile fabrics there. The northwest-southeast trend of both bedrock geologic contacts and internal structure is very prominent on the ridge south of Miers Valley (Figure 3). Both banding in metasedimentary marble along the southern margin of Miers Valley and foliation along the intrusive margin of the Bonney Pluton to the south are clearly visible. Although the origin of this structural grain could not be discerned from the DEM alone, the pervasive nature of this closely-spaced trend would point to an origin as bedding, banding, or ductile fabric. To the south of Hidden Valley, no such pervasive NW-SE trend is visible. Bedrock in that area consists of nonfoliated granite (Jones, 1997). The change from foliated to isotropic bedrock structure is thus discernible from analysis of the DEM. A prominent northeast-southwest trending igneous dike swarm traverses the Denton Hills region, cutting across older Ross fabrics (Janosy, 1994; Jones, 1997). A set of northeast features is very evident on the ALS DEM (Figures $2 \& 3$ ). Shaded-relief images show that many northeast-trending geomorphic elements stand up in relief relative to surrounding bedrock. Such relief is most typical of resistant rocks, and the positive relief of narrow, tabular bodies surrounded by low-relief homogeneous bedrock provides an important indicator that these are igneous dikes. Although the dikes can be traced for kilometers along strike, many are clearly divided into segments 10 s to 100 s of meters in length (Figure 3). The segments are typically arranged in a right-stepping geometry from south to north, commonly shifting position across northwest-trending, low-relief lineaments. Two explanations are possible for this dike geometry. The NW-trending lineaments could mark right-lateral faults that are younger than, and displace, the dikes. This relationship has been interpreted from relations mapped in the field and on aerial photographs by both Janosy (1994) and Jones (1997). Alternatively, the segmented geometry could represent an original intrusive geometry, as en echelon segments are a typical architecture of many dikes (e.g., Delany et al., 1986). More extensive field observations would be required to distinguish between these models, yet the DEM serves to identify structural geometries and facilitates formulation of testable hypotheses prior to field work.

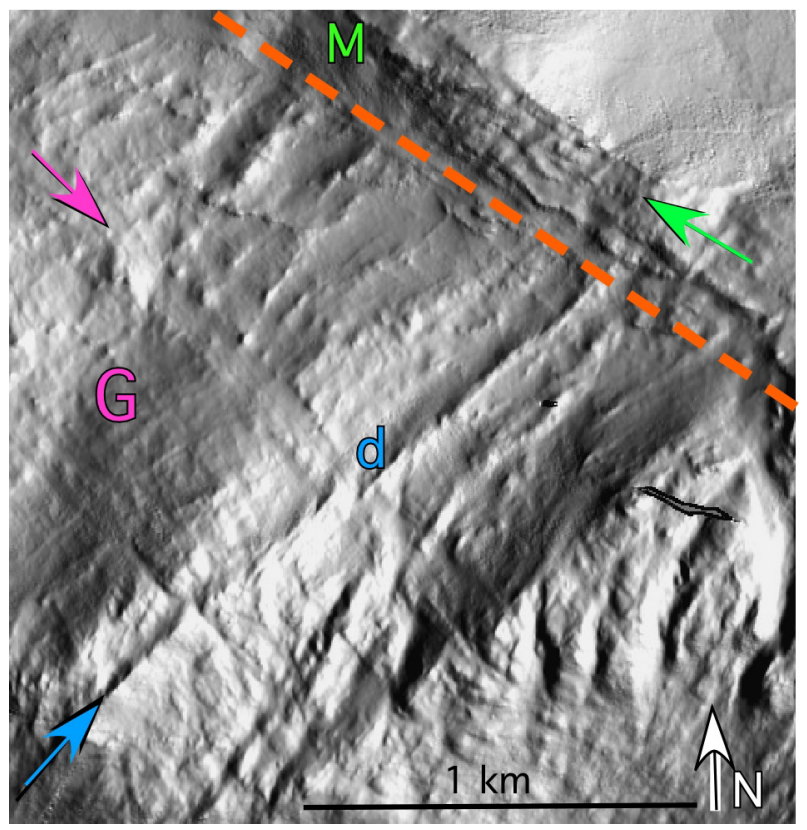

Figure 3. Shaded-relief image with sun illumination angle of $45^{\circ}$ from azimuth of $90^{\circ}$. Ross orogen ductile fabrics in marble $(M$, green arrow) and granite $(G$, pink arrow) trend northwest, and are cut by a dike swarm (d, blue arrow) that trends northeast. Note the right-stepping segments in the dike. Location shown on Figure 2.

\section{Rift-flank structure}

Linear features with negative relief are prominent across ridges of the Denton Hills and have both northwest and northeast trends (Figures $2 \& 4$ ). The straight traces across topography indicate that these are steeply dipping structures. Jones (1997) documented NE-SW hydrothermally-altered extension fractures and quartz veins parallel to the dike swarm. Jones (1997) and Janosy (1994) mapped NW-SE dextral strike-slip faults that 
offset the NE dikes and vein-filled extension fractures. Both sets formed after the Ross orogeny, but the only younger age constraint comes from overlap of the lineaments by Quaternary deposits. Thus the faults could mark very late-stage brittle deformation of the Ross orogeny, or deformation due to Cenozoic rifting and riftflank uplift as found in the coastal zone of the Dry Valleys to the north (Fitzgerald, 1992; Wilson, 1992, 1995).

The ALS DEM shows the NW and NE lineaments very clearly. There are mutual crosscutting relations visible on the DEM, for example near Holiday Peak between Miers and Adams Glaciers (Figure 4). The crosscutting lineaments are nearly perpendicular, rather than having a $60^{\circ}$ angle between them that is typical of conjugate faults. These relations suggest that the NW and $\mathrm{NE}$ lineaments represent reactivation of pre-existing structures that were in favorable orientations for movement under younger stress fields.

Jones (1996) mapped a northeast-trending fault that offsets inferred Quaternary deposits within a hanging valley toward the east end of Hidden Valley. This fault can be delineated on obliquely-illuminated shaded-relief

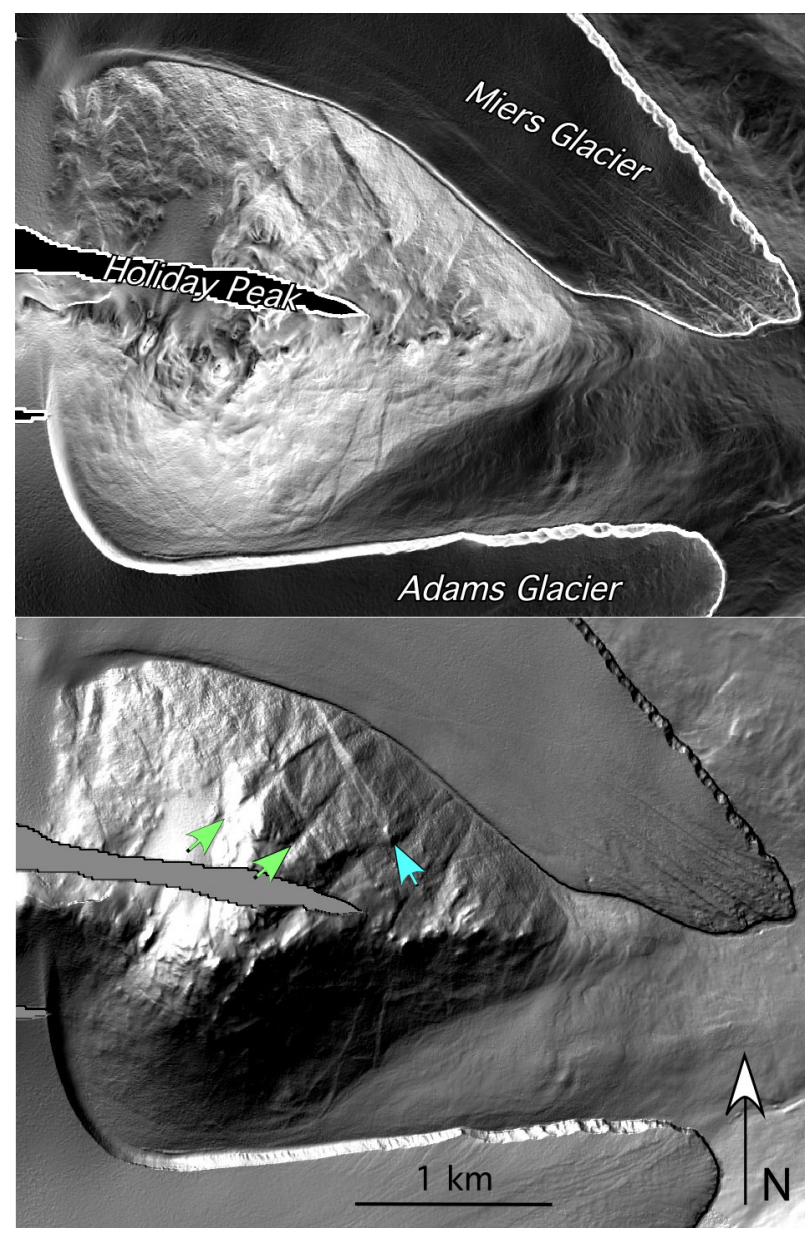

Figure 4. Crosscutting northeast (green arrows) and northwest (blue arrow) lineaments at Holiday Peak, shown on slope map (top) and relief map with illumination from azimuth $315^{\circ}$ (bottom). Location shown on Figure 2. images of the DEM (Figure 5). This cross-cutting relation shows that at least some component of the brittle structures marked by lineaments are young, rift-related faults.

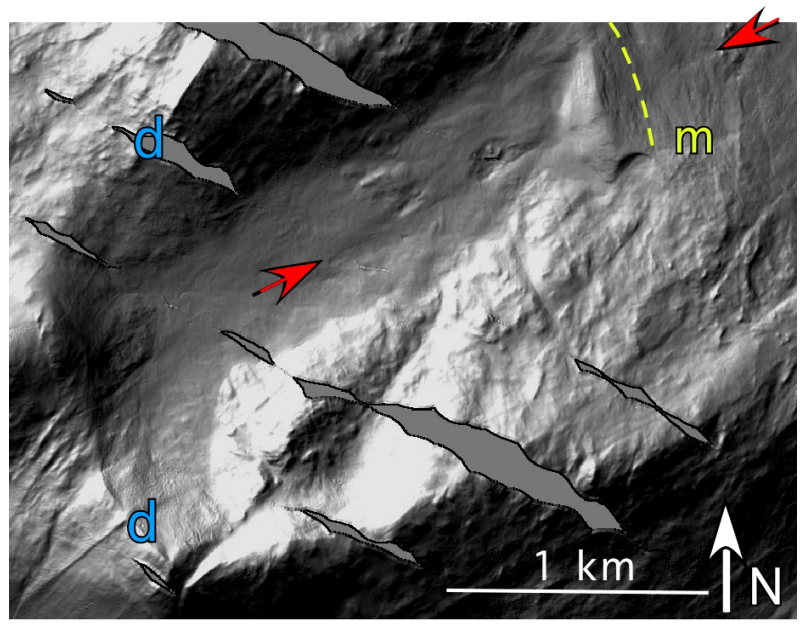

Figure 5. Fault cutting terminal moraine $(\mathrm{m})$ of hanging valley; Jones (1996) documented sinistral strike separation. Shown on relief map with illumination from azimuth $0^{\circ}$. Subparallel, NE-trending, Paleozoic dikes denoted by ' $d$ '. Location shown on Figure 2.

\section{Glacial geology}

The large ice-free area of the Denton Hills contains a variety of landscapes, including perennially ice-covered lakes, ephemeral streams, glaciers and extensive areas of soils and exposed bedrock. The new, high resolution, accurate DEM allows systematic geomorphologic mapping needed to understand the glacial history and climate evolution of the region.

\section{Ross Sea drift limit}

The Ross Sea drift occurs along the coastal margin and marks the western limit of the advance of grounded ice into the valleys of the Denton Hills at the LGM (Denton and Marchant, 2000). The sharp ice-cored moraine ridge at the upper boundary of the drift on the eastern slopes of coastal foothills is clearly demarcated on the DEMs (Figures 2 and 6). On the valley floors the drift sheet extends inland as glaciolacustrine sediments. These sediments were deposited from proglacial lakes, dammed by lobes of the Ross Sea Ice Sheet during the LGM (Hall et al., 2006).

\section{Lake-ice conveyor morphology}

A model for deposition of drifts, mounded features, and cross ridges by the 'lake-ice conveyor' mechanism has been developed to explain the geomorphology, sedimentology and age of the lacustrine sediments frequently occurring on valley floors inland of the edge of the Ross Sea Ice Sheet (Clayton-Greene et al., 1988; Hall et al., 2006). Lake ice conveyors facilitate the movement of glacial sediments across perennially frozen proglacial lakes, depositing those often tens of kilometers beyond 
the grounding line of the glacier. Conveyor deposits can be distinguished from sediments formed by direct polar glacier sedimentation, based on differences in grain size, stratification, organic material content, age distribution and their relationship to preexisting landforms. They often contain sediment layers with datable algal mats and carbonate layers and usually drape over pre-existing topography. Miers Valley displays a classical, well documented conveyor sequence (Hall et al., 2006). The new DEM allows geomorphologic mapping this sequence with unprecedented detail. Proglacial Lake Trowbridge, occupying the valley during the LGM, extended to more than $156 \mathrm{~m}$ above present day sea level during its maximum extent 18-19 ky ago as indicated by surficial carbonate deposits on the northern valley wall (ClaytonGreene et al., 1988; Figure 6).

The shaded relief DEM clearly depicts lake ice conveyor deposits, including moat lines, cross valley ridges and arcuate ridges (Figure 6). Moat lines are small ridge segments and mounds, formed along margins of proglacial lakes from the coarse debris melting out of the lake ice during the summer. A sequence of prominent moat deposits occurs along the northern valley wall (Figure 6), suggesting that the eastern basin of proglacial Lake Trowbridge drained in several stages. Three large, 10 meter high and 100 meter wide cross-valley ridges were mapped on the valley floor by Clayton-Greene et al. (1988), and another, similar ridge is indicated higher in the valley by the LIDAR DEM (Figure 6). They curve toward the valley wall, joining with the moat deposits, indicating that they were deposited during the drainage of the lake. Smaller arcuate ridges (5 m high, $50 \mathrm{~m}$ wide) are draped over the southernmost cross-valley ridge. Near the mouth of Miers Valley the DEM depicts a series small, parallel ridges that are typically $1 \mathrm{~m}$ high and 10$25 \mathrm{~m}$ wide. The western basin of Miers Valley is occupied by the perennially ice-covered Lake Miers. The LIDAR DEM depicts several ridges, parallel with the western lake shoreline. We interpret these ridges as moat deposits with the highest moat line, at 187 meter above present day sea level, marking the maximum extent of Lake Trowbridge during the operation of the lake-ice conveyor.

\section{Glacial Lake Trowbridge shorelines}

Paleoshorelines of the large lake that occupied the Miers Valley are clearly visible on the DEM (Figure 6). The elevation and any tilt of these shorelines are important markers for isostatic uplift since the LGM. These shorelines are above the maximum elevation of proglacial Lake Trowbridge indicated by surficial carbonate deposits.

\section{Discussion}

The high-resolution DEMs for the Denton Hills that have been produced from ALS data illustrate the wealth of detail that these new data supply for mapping applications. Bedrock ductile structure is very well defined in the form of pervasive, closely-spaced relief
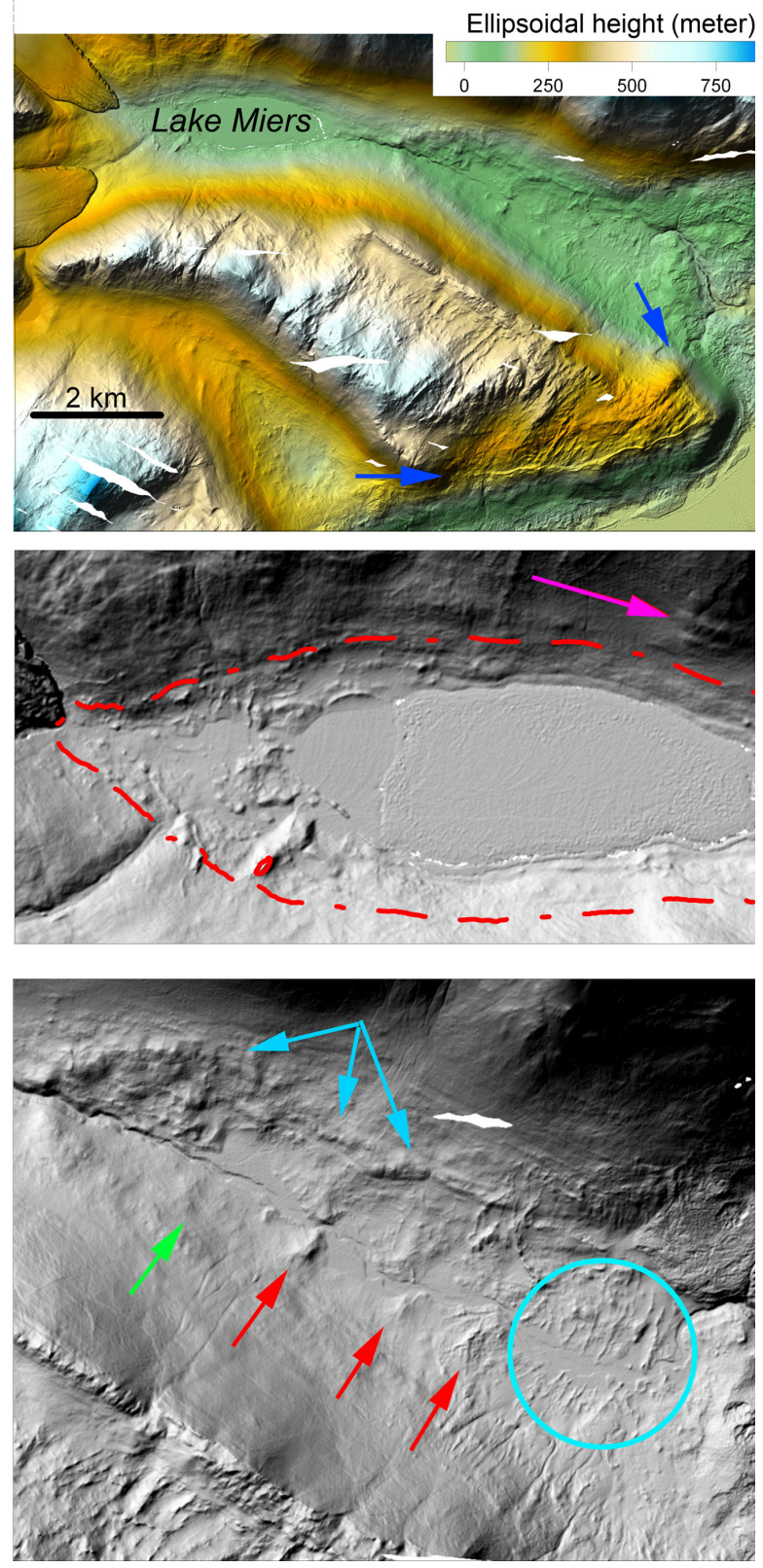

Figure 6. Glacial features of Miers Valley. Upper panel: shaded relief DEM of Miers Valley. Blue arrows point to moraine ridge of Ross Sea drift. Middle panel: western basin of Miers Valley with Lake Miers. Red dashed line indicates elevation of inferred highest moat line at 188 meter above sea level, purple arrow points to former shorelines. Lower panel: eastern basin of Miers Valley. Red arrows point to cross-valley ridges mapped by Clayton-Greene et al. (1988), green arrow shows crossvalley ridge indicated by LIDAR DEM, blue arrows point to moat ridges and blue circle shows the area with narrow, parallel cross-valley ridges. Illumination from NW $\left(315^{\circ}\right)$. Location shown in Figure 2. 
trending northwest, where preferential erosion along banding and foliation planes has produced low-relief morphology. Dike planes that crosscut the ductile fabrics have positive relief and are effectively highlighted by shadowing in shaded-relief images. Details of dike geometry, such as segmentation, are obvious on the DEMs. Lineaments etched into bedrock occur in both northwest and northeast orientations, and most likely represent fault arrays and associated fracture planes. Though the ages of these brittle structures are poorly constrained, at least some are neotectonic faults as shown by the northeast-trending lineament cutting a hanging valley terminal moraine. Glacial features have expression that is equally striking on the DEMs. In addition to the ability to map the extent of glacial features spatially, the high-resolution topographic data makes it possible to quantify feature height, length and breadth, and to systematically measure such aspects as paleoshoreline elevations across the region.

\section{Summary}

New high-resolution topographic data for the Denton Hills region was obtained by airborne laser scanning using NASA's ATM system. Processing techniques are described to produce enhanced DEM images that increase visibility of structural and glacial features and help to define aspects that allow feature origin to be determined. Ductile and brittle structural trends related to the Ross orogen are identified, including metasedimentary banding, foliation in plutonic rocks, and a cross-cutting dike swarm. Two lineament sets mark brittle faults and fractures that post-date Ross main-phase deformation and at least some of these structures are related to rifting and neotectonic faulting. Mappable glacial features include the western limit of the Ross Sea drift, ridges and mounds interpreted as lake-ice conveyor deposits from proglacial lakes, and uplifted lake shorelines providing markers for documentation of postglacial rebound magnitude and rates. Combining field-based feature identification with high-resolution ALS topographic data clearly has significant potential for structural and glacial geomorphic mapping in the Transantarctic Mountains.

Acknowledgments. We thank members of NASA's ATM group, especially Bill Krabill, for collecting and processing the data; Toni Schenk and students of OSU PCVL for postprocessing the laser point cloud; Cheryl Hallam of the USGS; and Scott Borg of NSF-OPP for supporting the ALS data acquisition trial. B. Csatho acknowledges support for this work from NSF grant OPP-0233246 and from NASA's ICESat program. Brenda Hall and Michael Studinger are thanked for helpful reviews of this manuscript.

\section{References}

Atkins, C.B., and W.W. Dickinson (2007), Landscape modification by meltwater channels at margins of cold-based glaciers, Dry Valleys, Antarctica, Boreas, DOI 10.1080/03009480600827306.

Carter, W., R. Shrestha, G. Tuell, D. Bloomquist, and M. Sartori (2001), Airborne laser swath mapping shines new light on Earth's topography, Eos Trans. AGU, 82(46), 549-550, 555.
Clayton-Greene, J.M., C.H. Hendy, and A.G. Hogg, (1988), Chronology of a Wisconsin age proglacial lake in the Miers Valley, Antarctica. N.Z. J. Geol. Geophys., 31, 353-361.

Csatho, B., Y-R. Lee, T. Schenk, W. Krabill and J. McGarry, (2001), Creation of high resolution, precise digital elevation models of Ocean City and Assateague Island, MD, International Archive of Photogrammetry and Remote Sensing, 34(3 W4), 31-35.

Csatho, B., T. Schenk, W. Krabill, T. Wilson, W. Lyons, G. McKenzie, C. Hallam, S. Manizade, and T. Paulsen, (2005), Airborne laser scanning for high-resolution mapping of Antarctica, EOS, Transactions, 86 (25), 237-238.

Cunningham, D., S. Grebby, K. Tansey, A. Gosar and V. Kastelic, (2006), Application of airborne LIDAR to mapping seismogenic faults in forested mountainous terrain, southeastern Alps, Slovenia, Geophysical Research Letters, 33, L20308, doi:10.1029/2006GL027014.

Delaney, P.T., D.D. Pollard, J.I. Ziony, and E.H. McKee, (1986), Field relations between dikes and joints: Emplacement processes and paleostress analysis, Journal of Geophysical Research, 91, 4920-4938.

Denton, G.H., and D.R. Marchant, (2000), The geologic basis for a reconstruction of a grounded ice sheet in McMurdo Sound, Antarctica, at the last glacial maximum, Geogr. Ann. 82A, 167-211.

Fitzgerald, P.G., (1992), The Transantarctic Mountains of southern Victoria Land: The application of apatite fission track analysis to a rift shoulder uplift, Tectonics, 11, 634-662.

Hall, B.L., C.H. Hendy, and G.H. Denton, (2006), Lake-ice conveyor deposits: Geomorphology, sedimentology, and importance in reconstructing the glacial history of the Dry Valleys, Geomorphology, $75,143-156$.

Haugerud, R., D. J. Harding, S. Y. Johnson, J. L. Harless, C. S. Weaver, and B. L. Sherrod, (2003), High-resolution LIDAR topography of the Puget Lowland, Washington-A bonanza for Earth science, GSA Today, 13(6), 4-10.

Janosy, R.J., (1994). Structural investigations of the early Paleozoic Victoria Land dike swarm in the Ferrar-Koettlitz Glacier region, southern Victoria Land, Antarctica. Thesis (Master's)--Ohio State University, Columbus, $\mathrm{OH}$.

Jones, S., (1996), Late Quaternary faulting and neotectonics, South Victoria Land, Antarctica, Journal of the Geological Society of London, 143, 645-652.

Jones, S., (1997), Structural inheritance from crustal anisotropy, South Victoria Land, Antarctica, in: Ricci, C.A. (Editor), The Antarctic Region: Geological Evolution and Processes, Terra Antartica Publication, Siena, 571-576.

Krabill, W. B., W. Abdalati, E. B. Frederick, S. Manizade, C. F. Martin, J. G. Sonntag, R. N. Swift, R. H. Thomas, and J. G. Yungel (2002), Aircraft laser altimetry measurement of elevation changes of the Greenland ice sheet: Technique and accuracy assessment, J. Geodyn., 34, 357-376.

Lyons, W.B., K.A. Welch, A.E. Carey, D.H. Hall, R.A. Virginia, A.G. Fountain, P.T. Doran, B.M. Csatho and C.M. Tremper, 2005. Groundwater seeps in Taylor Valley, Antarctica: An example of a subsurface melt event, Annals of Glaciology, 40, 200-206.

Stump, E., (1995), The Ross Orogen of the Transantarctic Mountains. Cambridge University Press, 284 p.

Sugden, D.E., M.A. Summerfield,G.H. Denton, T.I. Wilch, W.C. McIntosh, D.R. Marchant, and R.H. Rutford, (1999), Landscape development in the Royal Society Range, southern Victoria Land, Antarctica: stability since the mid-Miocene, Geomorphology, 28, 181-200.

Wilson, T.J., (1992), Mesozoic and Cenozoic kinematic evolution of the Transantarctic Mountains, in Yoshida, Y., K. Kaminuma, and K. Shiraishi (eds.), Recent Progress in Antarctic Earth Science, Tokyo, Terra Scientific Publishing Co., 303-314.

Wilson, T.J., (1995), Cenozoic transtension along the Transantarctic Mountains - West Antarctic rift boundary, southern Victoria Land, Antarctica, Tectonics, 14, 531-545. 